\title{
INTERNATIONAL RESEARCH CAPACITY BUILDING PROGRAM FOR HEALTH RELATED PROFESSIONALS TO STUDY THE DRUG PHENOMENON IN LATIN AMERICA AND THE CARIBBEAN
}

\author{
Maria da Gloria Miotto Wright ${ }^{1}$, Francisco Cumsille², Maria Itayra Padilha ${ }^{3}$, Carla Arena Ventura ${ }^{4}$, Jaime \\ Sapag ${ }^{5}$, Bruna Brands ${ }^{6}$, Hayley Hamilton ${ }^{7}$, Robert Mann ${ }^{8}$, Akwatu Khenti ${ }^{9}$
}

\begin{abstract}
${ }^{1}$ Ph.D. Former Coordinator Educational Development Program. Interamerican Drug Abuse Control Commission (CICAD), Secretariat for Multidimensional Security. Washington, USA. E-mail: gloriamiottowright@gmail.com

2 Ph.D. Head of Interamerican Drug Observatory CICAD, OAS. Washington, USA. E-mail: fcumsille@oas.org

${ }^{3}$ Ph.D. Academic Coordinator of the OAS, Secretariat for Multidimensional Security (SMS), CICAD, Centre for Addiction and Mental Health, (CAMH) International Research Capacity Building Program from 2009 to 2013. Dean and Associate Professor of Nursing Department, Federal University of Santa Catarina, Florianópolis, Brazil. E-mail: itayra.padilha@ufsc.br

${ }^{4}$ Ph.D. Academic Coordinator of the OAS/SMS/CICAD-CAMH International Research Capacity Building Program in 2014, Associate Professor at the University of São Paulo at Ribeirao Preto, School of Nursing, Brazil. E-mail: caaventu@eerp.usp.br

${ }^{5}$ Ph.D. Former Scholar of Transformative Global Health Office, CAMH. Toronto, Canada. E-mail: jaimesapag@camh.ca

${ }^{6}$ Ph.D. Senior Scientist. Office of Research and Surveillance, Drug Strategy and Controlled Substances Programme, Health Canada and Public Health and Regulatory Policies CAMH, University of Toronto, Canada. E-mail: bruna.brands@camh.ca

${ }^{7}$ Ph.D. Investigator. CAMH, University of Toronto. Toronto, Canada. E-mail: hayley.hamilton@camh.ca

${ }^{8}$ Ph.D. Investigator. CAMH, University of Toronto. Toronto, Canada. E-mail: robert.mann@camh.ca

${ }^{9}$ Doctor Student. Director, Transformative Global Health Office, CAMH. Toronto, Canada. E-mail: akwatu.khenti@camh.ca
\end{abstract}

\begin{abstract}
Most Organization of American States member states do not have a cadre of professionals with scientific knowledge and research experience on drugs and related problems. Therefore, the Organization of American States started a partnership, first with the University of Alberta/Canada and then with the Centre for Addiction and Mental Health in Toronto/Canada to train health related professionals to address this problem. The objective is to create a cadre of health and related professionals with scientific and technical research knowledge to enable scientific advances in the area of drug demand reduction. The program requires the development and implementation of a multicentric drug research proposal. The program has produced the following results: nine multicentric drug research studies implemented in 22 countries of Latin America and the Caribbean; 91 participants from 22 countries of Latin America and the Caribbean. This is the only program in the Americas offering continued advanced research training to university faculty and contributing to strengthen the undergraduate and graduates curriculum on drug issues and research capability in Latin America and the Caribbean.
\end{abstract}

DESCRIPTORS: Narcotics. Research. Capacity building. Latin America. Caribbean.

\section{PROGRAMA INTERNACIONAL DE CAPACITAÇÃO EM PESQUISA PARA PROFISSIONAIS DE SAÚDE SOBRE O ESTUDO DO FENÔMENO DAS DROGAS NA AMÉRICA LATINA E CARIBE}

\begin{abstract}
RESUMO: A maioria dos países membros da Organização dos Estados Americanos não possui um conjunto de profissionais com experiência em pesquisa e conhecimento científico sobre drogas e problemas relacionados. Assim, a Organização dos Estados Americanos iniciou uma parceria, primeiro com a Universidade de Alberta/Canada, e depois, com o Centro de Adição e Saúde Mental em Toronto/ Canada, para capacitar profissionais das áreas relacionadas a saúde para desenvolverem pesquisas sobre o problema das drogas. O programa tem o objetivo de criar um grupo de profissionais de áreas relacionadas à saúde, com conhecimento científico e técnico em pesquisa, para favorecer avanços científicos na área de redução da demanda de drogas. O programa exige o desenvolvimento e implementação de uma proposta multicêntrica de pesquisa sobre drogas. O programa tem produzido os seguintes resultados: nove estudos multicêntricos de pesquisa sobre drogas desenvolvidos em 22 países da América Latina e Caribe e 91 participantes de 22 países de América Latina y Caribe. Este é o único programa das Américas que oferece contínuo treinamento em pesquisa avançada para professores de universidades, além de contribuir para fortalecer os currículos dos cursos de graduação e pós-graduação em questões relacionadas às drogas e a capacidade de pesquisa na America Latina e Caribe.
\end{abstract}

DESCRITORES: Entorpecentes. Pesquisa. Fortalecimento institucional. América Latina. Caribe. 


\title{
PROGRAMA INTERNACIONAL DE CAPACITACIÓN EN \\ INVESTIGACIÓN PARA PROFESIONALES DE SALUD EN EL ESTUDIO DEL FENÓMENO DE LAS DROGAS EN AMÉRICA LATINA Y CARIBE
}

\begin{abstract}
RESUMEN: La mayoría de los países miembros de la Organización de los Estados Americanos no tienen un grupo de profesionales con experiencia en investigación y conocimiento científico en drogas y problemas relacionados. Así, la Organización de los Estados Americanos empezó, una asociación, primero con la Universidad de Alberta/Canadá y después con el Centro de Adición y Salud Mental en Toronto/Canadá para capacitar profesionales de áreas relacionadas a la salud para desarrollaren investigaciones sobre el problema de drogas. El programa tiene el objetivo de crear un grupo de profesionales de áreas relacionadas de la salud con conocimiento científico y técnico en investigación para favorecer los avances científicos en el área de reducción de la demanda de drogas. El programa requiere el desarrollo e implementación de una propuesta multicentrica de investigación sobre drogas. El programa tiene producido los siguientes resultados: nueve estudios multicentricos de investigación sobre drogas desarrollados en 22 países de América Latina y Caribe; 91 participantes de 22 países de América Latina y Caribe. Este es el único programa en las Américas que oferta continuamente el entrenamiento en investigación avanzada para profesores universitarios y contribuye para fortalecer los currículos de los cursos de pregrado y post grado en cuestiones sobre drogas y la capacidad de investigación en América Latina y Caribe.
\end{abstract}

DESCRIPTORES: Narcóticos. Investigación. Creación de capacidad. América Latina. Caribe.

\section{INTRODUCTION}

Illicit drug use is one of the top twenty global health risk factors - a problem which affects approximately 210 million people annually, with a related mortality rate of nearly $200,000 .{ }^{1}$ Issues stemming from the drug phenomenon include drug-related health problems, organized crime, violence and other social and economic problems. ${ }^{1}$

The drug phenomenon has become a complex, dynamic and multi-causal problem that presents a difficult challenge to States and their governments around the world. This phenomenon demands a comprehensive, balanced and multidisciplinary approach with a shared responsibility among those involved. Drug policies for the hemisphere should focus not only on supply and control, but also on drug dependence. This new strategy explicitly recognizes that drug dependence is a chronic disease - not unlike diabetes, hypertension or asthma - all of which requires proper medical care to address various symptoms, as well as treat the underlying causes. Therefore, the new strategy recommends that drug dependence must be addressed as a core element of public health policy. ${ }^{2}$

A new and improved paradigm is required to address the underlying causes of the drug phenomenon in the States. This paradigm should focus on three main goals: (a) treating drug use as a matter of public health, (b) reducing drug consumption through information, education and prevention, and (c) repressing organized crime. ${ }^{3}$

Considering the need for innovative approaches to deal with the drug phenomenon in the Americas, the purpose of this paper is to describe the collaboration between the Inter-American
Drug Control Commission (CICAD) and the Center for Addiction and Mental Health (CAMH) to implement the International Research Capacity Building Program for Health Related Professionals to Study the Drug Phenomenon in Latin America and the Caribbean.

\section{JUSTIFICATION}

The challenges imposed by the drug phenomenon require the formulation of partnerships and innovative approaches towards educating health professionals in the Americas. The current global context requires specialized individuals who are able to analyze problems and propose empirically-based solutions and/or strategies for national and international audiences.

The majority of the countries in Latin America and in the Caribbean do not have a cadre of professionals with scientific knowledge and research experience regarding drug use and related issues. These assets are important when conducting work for national drug commissions, research centers, or academy. Further, many countries have not yet to establish programs or long-term plans for the development of research on the drug phenomenon, and have failed to incorporate large-scale results in the development of national drug control policies.

As a solution, low and middle income countries have partnered with developed countries to design strategies for professional advancement in the study of the drug phenomenon. International organizations have collaborated with their member states on strengthening institutional capacity and human resources in relation to issues stemming from the drug phenomenon, including security, money-laundering and drug demand reduction. 
Specifically, in the region of the Americas, $94 \%$ of countries offered training pertaining to drug demand reduction (prevention and treatment). Beneficiaries included professional and technical personnel working in areas of addiction, such as police officers, teachers, counselors, prison guards, instructors and community leaders. A diverse range of topics was made available to participants, including: awareness of, and multidisciplinary approaches to, drug addiction; appropriate program application methods for diverse populations and environments; and refresher/ advanced training in prevention and treatment. ${ }^{4}$

Although some countries include a prevention component in the professional curricula of health and social sciences (nursing, public health, social work, etc.), other countries continue to demonstrate weaknesses in terms of accurately distinguishing between drug prevention programs and ad hoc activities or interventions. Such activities, including conferences, lectures, symposium and contests, are not part of comprehensive prevention strategies. These countries need to focus efforts on capacity-building in order to develop and deliver appropriate prevention programs that will facilitate scientific evaluations. ${ }^{4}$

Some international organizations have developed joint initiatives regarding drug dependence treatment and care, that stress that services must address drug use disorders in a pragmatic, science-based, and humanitarian way. To do so, this initiative calls for the development of a comprehensive, health-based approach to drug policy that can reduce demand for illicit substances, relieve suffering, and decrease drug-related harm affecting multiple facets of society. ${ }^{5}$

There are few drug research capacity-programs in the Americas that are continually offered to health professionals. One of the first research agencies to adopt a public health, evidence-based approach to drug abuse and addiction is in the United States. Since its conception in 1990, this agency has built partnerships with countries, organizations, and individual researchers to advance multinational cooperation, promote new research initiatives, expand international research capacity, and share knowledge about drug abuse and addiction. By promoting regional and global scientific networks, this organization disseminates research methods and findings around the world, whilst simultaneously introducing grantees to talented drug abuse researchers from other countries. Facilitating this collaboration encourages the discovery of evidence-based interventions, and contributes to global efforts to develop, adopt, and evaluate government policies, prevention programs, and treatment protocols that effectively address drug abuse and its consequences. ${ }^{6}$

Following this same line of orientation, the Organization of American States (OAS), the Secretariat for Multidimensional Security (SMS) and CICAD has partnered with the CAMH since 2006 to offer the International Research Capacity-Building Program for Health and Related Professionals to Study the Drug Phenomenon in Latin America and the Caribbean. As a unique experience in the Americas, this initiative has facilitated the training of Latin American and Caribbean university researchers in advanced drug research methodology. This training enables researchers to conduct multicentric studies regarding drug related issues specifically pertaining to five programmatic areas of demand reduction: promotion of healthy and sustainable lifestyles, prevention of drug use and abuse, treatment, rehabilitation and social integration.

\section{FRAMEWORK}

The complexities of the drug phenomenon demand the adoption and application of a broader and holistic perspective. The national, international and global consequences of the drug problems urge each State in the hemispheric area to work together in cooperation and partnership. This calls for a framework that supports the analysis and decision making required for policy, program and project design in accordance with this new perspective.

Figure 1 presents the Critical-Holistic International Health Model $^{7}$ applied to the analysis and work of the drug phenomenon. This model offers a multidimensional view, as well as a critical-holistic perspective of the interaction, integration and balance of the drug phenomenon components. According to this framework, the drug phenomenon should be seen as the interrelationship between national and international dimensions, and the ultimate impacts at a global level. ${ }^{8}$ Therefore, the drug phenomenon is a social problem, with its determinants and conditioning factors ranging from ethical-legal, agro-ecological, cultural, spiritual, economic, political and technological aspects all of which have an impact on the health of the individual, family and community. To understand these interrelationships, it is important to consider four major concepts that affect the process of policy design and decision making: power, interest, knowledge and leadership. ${ }^{9}$ 
The Critical-Holistic International Health Model (Figure 1) applied to the Drug Phenomenon was used as a framework to support the design and implementation of the International Research
Capacity-Building Program for Health and Related Professionals to Study the Drug Phenomenon in Latin America and the Caribbean at CAMH, Toronto, Canada.

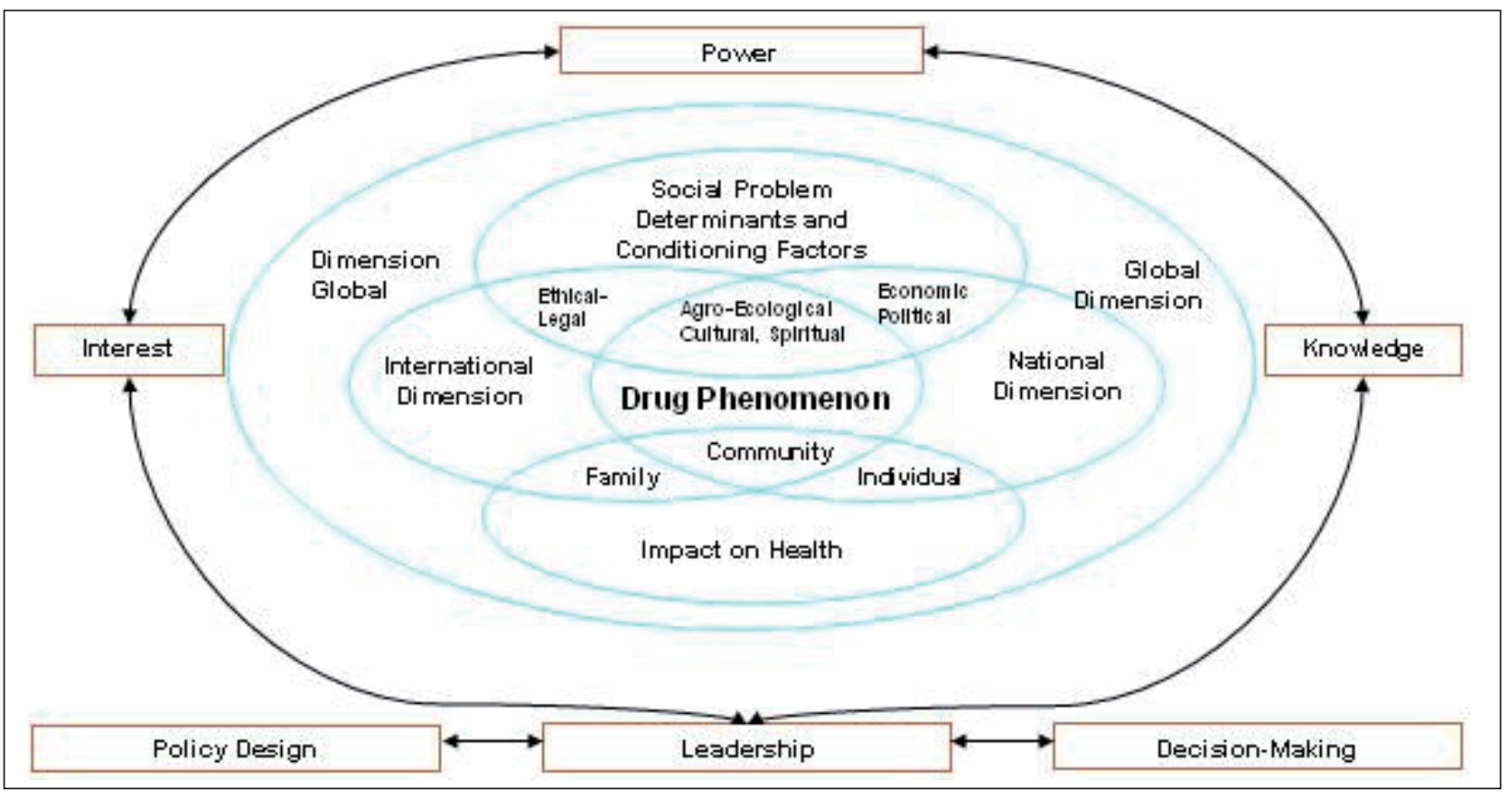

Figure 1 - Critical-Holistic International Health Model applied to the Drug Phenomenon. USA, 2000

\section{TECHNICAL AND FINANCIAL COOPE- RATION}

The new Hemispheric Drug Strategy ${ }^{9}$ recommends the promotion of international cooperation programs among member states in order to strengthen national policies and provide technical assistance. This will allow for the exchange of best practices and lessons learned when addressing the world drug problem in regards to institutional capacity, supply and demand reduction, and control measures.

The Plan of Action of the new Hemispheric Strategy ${ }^{10}$ states that international cooperation should promote technical assistance, financing, and training to facilitate compliance with the recommendations formulated under the framework of the Multilateral Evaluation Mechanism (MEM). In addition, the strategy further expresses the need to strengthen government relationships by employing academic and research institutions to generate evidence regarding the demand for drugs.

In 2005, ES/CICAD invited CAMH to collaborate on the implementation of the International Research Capacity-Building Program for Health and Related Professionals to Study the Drug Phenomenon in Latin America and the Caribbean. This was achieved through a technical and finan- cial cooperation supported by the Government of Canada/Foreign Affairs and International Trade Canada (DFAIT). During 2003-2004, a pilot of the program was completed with 11 nurses and the support of the Faculty of Nursing at the University of Alberta/Canada. ${ }^{11}$

In 1986, the CICAD was established by the General Assembly of the OAS as the Western Hemisphere's policy forum regarding all aspects of the drug phenomenon. CICAD's core mission is to enhance the human and institutional capabilities of its members to reduce the production, trafficking, and use and abuse of illegal drugs. Further, it sets out to address the health, social and criminal consequences of the drug trade.

CICAD is the OAS Secretariat that:

- $\quad$ Fosters multilateral cooperation regarding drug issues in the Americas.

- $\quad$ Executes action programs to strengthen the capacity of CICAD member states in order to prevent and treat licit and illicit drug abuse; combat production of illicit drugs; deny traffickers their illegal profits.

- $\quad$ Promotes drug-related research; information exchange; specialized training; technical assistance. 
- Develops and recommends minimum standards for drug-related legislation and treatment; measurement of both drug consumption and the cost of drugs to society; drug-control measures.

- Carries out regular multilateral evaluations of progress by member states in all aspects of the drug problem (Multilateral Evaluation Mechanism).

The CAMH is Canada's leading addiction and mental health institution, as well as a Pan American Health Organization (PAHO) and World Health Organization (WHO) Collaborating Centre fully affiliated with the University of Toronto. In June 2002, CAMH launched the Office of International Health $(\mathrm{OIH})$ to address the growing global burden of addiction and mental illness borne by underresourced regions of the world. Since its creation, the Office of Transformative Global Health (OTGH) has been working with countries in various regions of the world including Africa, Latin America and the Caribbean (LAC), and South Asia to strengthen mental health and addiction capacity at local, regional and national levels.

The International Research Capacity-Building Program for Health and Related Professionals to Study the Drug Phenomenon in Latin America and the Caribbean has been implemented at CAMH through the OTGH from 2006 to present.

\section{Educational program}

The purpose of the International Research Capacity-Building Program for Health and Related Professionals to Study the Drug Phenomenon in Latin America and the Caribbean is to create a cadre of health-related professionals with specialized scientific knowledge and research skills in regards to drug-related issues. These assets are to be applied at various levels, including policy design, decision making, research programs, project implementation, and management and evaluation.

The aims of the program are:

- $\quad$ To strengthen the scientific knowledge and technical research skills among university faculty.

- $\quad$ To study the drug issues and related problems at the levels of policy design, decisionmaking and programs.

- $\quad$ To provide research management skills for implementation, evaluation and knowledge translation.

This one year academic program consists of 1116 hours - 466 hours of on-site training in Canada, and 650 hours to conduct a multicentric research study in the countries of origin. The first portion of the program dedicates two weeks to reinforcing language skills (English and Spanish, depending on the need) and provides a review of aspects of Canadian culture. This is followed by two months of in-class training at $\mathrm{CAMH}$, as well as the formulation of a multicentric research study. Program faculty consists of well known CAMH researchers and academics proficient in various areas the program. An adult education learning format is employed in order to enable learning and collaborative work with the ten participants from various countries in Latin America and the Caribbean (see Table 1). The second component of the program pertains to the implementation of the research study in the participants' native countries during a period of eight and a half months.

Table 1 - General Characteristics of the Education Program, Toronto, Canada, 2014

\begin{tabular}{|l|l|}
\hline Number of hours & $\begin{array}{l}466 \text { hours (Part I) } \\
650 \text { hours (Part II) } \\
\text { Total: 1116 hours }\end{array}$ \\
\hline Type of program & $\begin{array}{l}\text { Post - doctorate (participants with PhD) } \\
\text { Specialization (participants with MSc) }\end{array}$ \\
\hline Length & $\begin{array}{l}\text { 1 year, divided as follows: } \\
\text { Part I: Theory and practice of program's content (Toronto, Canada) } \\
\text { Part II: Distance learning tutorial (country of origin) }\end{array}$ \\
\hline Faculty & $\begin{array}{l}\text { University of Alberta, Centre for Addiction and Mental health, University of Toronto, and Inter- } \\
\text { American Drug Control Commission }\end{array}$ \\
\hline Target & Health related professionals \\
\hline Language & English \\
\hline Type of research & $\begin{array}{l}\text { Multicentric research based in a central drug theme chosen with the group, along with CICAD's } \\
\text { priorities, countries priorities and interest of participants }\end{array}$ \\
\hline Funding & Government of Canada (2003-present) \\
\hline Association & $\begin{array}{l}\text { CICAD and the University of Alberta (first edition); subsequent editions with the Centre for Ad- } \\
\text { diction and Mental Health }\end{array}$ \\
\hline
\end{tabular}

Texto Contexto Enferm, Florianópolis, 2015; 24 (Esp): 17-25. 
The on-site training component includes seven sections: a one week pre-module to define the central theme of the multicentre study on drugs, followed by six academic modules (see Table 2):

- Drug issues in the Americas and in the world.

- International health and the drug phenomenon in the Americas and the world.
Research methodology (qualitative and quantitative).

- Creation and management of research groups and research exchange programs in the Americas.

- Communication and dissemination of research findings.

- $\quad$ Development of research proposal.

Table 2 - Academic curriculum of the program. Toronto, Canada, 2014

\begin{tabular}{|c|c|c|}
\hline Modules & Themes & Hours \\
\hline \multirow{2}{*}{ Pre-Module } & (i) English language and cultural aspects of Canadian society & 80 \\
\hline & (ii) Seminar for selection of central research theme for multicentric drug research proposal & 30 \\
\hline I & Drug problems in the Americas and the world & 20 \\
\hline II & International health and drug phenomenon in the Americas and the world & 20 \\
\hline III & Research methodology (qualitative and quantitative) & 120 \\
\hline IV & $\begin{array}{l}\text { Creation and management of research groups and research exchange programs in the } \\
\text { Americas }\end{array}$ & 20 \\
\hline $\mathrm{V}$ & Communication and dissemination of multicentric research findings & 16 \\
\hline VI & Development of multicentric drug research proposal & 160 \\
\hline VII & Implementation of the multicentric research project in the country of origin & 650 \\
\hline Total & & 1116 \\
\hline
\end{tabular}

A total of twenty two countries have been represented in the program from Latin America and the Caribbean from 2003-2013. The country with the highest representation in the program is Brazil (19); followed by Colombia (9); Jamaica (9); Nicaragua (8); Chile (7); El Salvador (5); Ecuador and Peru (4) each; Costa Rica, Guatemala, Guyana, and Mexico (3) each; Honduras, Panama, Trinidad \& Tobago, and Uruguay (2) each; Argentina, Bahamas, Barbados, Belize, Paraguay, and Suriname (1) each .

After the first offer in 2004, CICAD opened the program to all health related areas, and partnered with CAMH in 2006 to establish the International Research Capacity-Building Program (IRCBP). The academic areas represented in the program are: Nursing (41), Psychology (16), Medicine (13); Public Health (5); Education (4) Sociology and Social Work (2) each; Political Sciences, Statistics, Pharmacy, International Relations, and Occupational Therapy only with (1) participant each.

Table 3 provides the titles of the multicentric drug studies conducted by participants in the program. Five groups of program participants chose university students as their sample population. One group examined the relationship between drugs and violence among women, one group focused on the perspectives of family and familiars of illicit drugs users; another group on treatment centers, and another group on the urban attitudes. In addition, it is important to mention that program graduates have been involved in varying capacities in other studies developed by CICAD/ EDRS, The study on "Drugs, women and violence in 12 countries of the Americas" influenced the implementation of two similar studies in Latin America, one of them entitled "The nexus between drugs and violence in the Americas: a gender perspective" (ES/CICAD/OID/CAMH/10 countries - final study, in process to be implemented). The five studies related to university populations presented critical information that has yet to be addressed in the studies implemented by CICAD/ OIDS. The study on perceptions of family and familiars, "Illicit grug use in Canada-Toronto: critical perspectives of family and familiars" was replicated in Canada by CAMH to address an evidence gap for this subject in this country. The study conducted in the treatment centers was the first multicentric study implemented in Latin America and Caribbean countries related to this subject. The study on urban attitudes is also the first multicentric study carried out in Latin America and Caribbean countries. 
Table 3 - Titles of multicentric studies from 2003-2013 of the IRCBP (Canada), Toronto, Canada, 2014

\begin{tabular}{|c|l|}
\hline Year & \multicolumn{1}{c|}{ Program studies } \\
\hline $2003-2004$ & "Women, drugs and violence in Latin America" (exploratory study I) \\
\hline $2006-2007$ & "Illicit drug use in seven Latin American countries: critical perspectives of family and familiars". \\
\hline $2007-2008$ & $\begin{array}{l}\text { "University student's perceived norms about peers and drug use: a multicentric study from five Latin } \\
\text { America countries" }\end{array}$ \\
\hline $2008-2009$ & $\begin{array}{l}\text { "Simultaneous poly-drug consumption among undergraduate university students in six Latin Ameri- } \\
\text { can countries and in one Caribbean country: gender, legal and social implications" }\end{array}$ \\
\hline $2009-2010$ & $\begin{array}{l}\text { "A multicentric study of comorbidity between psychological distress and drug use among patients in } \\
\text { treatment centers, in seven countries of Latin America and one country in the Caribbean: policy and } \\
\text { program implications" }\end{array}$ \\
\hline $2010-2011$ & $\begin{array}{l}\text { "Drug use among university students and its relationship with maltreatment during childhood in } \\
\text { seven universities in Latin America and the Caribbean" }\end{array}$ \\
\hline $2011-2012$ & $\begin{array}{l}\text { "The role of family relations, spirituality and entertainment in moderating the relationship between } \\
\text { peer influence and drug use among university students in five countries of Latin America and three } \\
\text { countries in the Caribbean." }\end{array}$ \\
\hline $2012-2013$ & $\begin{array}{l}\text { "Knowledge of consequences, academic performance and drug consumption among undergraduate } \\
\text { university students in six Latin America and three Caribbean countries" }\end{array}$ \\
\hline 2013-2014 & "Urban attitudes toward persons who use drugs in five Latin America and five Caribbean Countries" \\
\hline
\end{tabular}

Table 4 summarizes the achievements of the program, with a total of 91 participants from 20032013. Further, it should be noted that more than 50 articles have been published in international jour- nals, more than 40 posters have been presented at international and national conferences, and a total of 8 posters have been presented at the NIDA/NIH International Research Forum.

Table 4 - Graduates and Products of IRCBP from 2003-2013. Toronto, Canada, 2014

\begin{tabular}{|c|c|c|}
\hline \multicolumn{2}{|c|}{ Graduates } & \multirow{3}{*}{\begin{tabular}{|l|}
\multicolumn{1}{|c|}{ Products } \\
$\begin{array}{l}\text { The graduates have already published more than } 50 \text { articles in inter- } \\
\text { national journals }\end{array}$
\end{tabular}} \\
\hline Group 2003-2004 & 11 graduates & \\
\hline Group 2006-2007 & 10 graduates & \\
\hline Group 2007-2008 & 10 graduates & \multirow{2}{*}{$\begin{array}{l}\text { The graduates have already presented more than } 40 \text { posters at Execu- } \\
\text { tive Secretariat/Inter-American Drug Control Commission/ Educa- } \\
\text { tional Development Program international meetings }\end{array}$} \\
\hline Group 2008-2009 & 10 graduates & \\
\hline Group 2009-2010 & 10 graduates & \multirow{5}{*}{$\begin{array}{l}\text { Eight posters were presented at National Institute on drugs abuse/ } \\
\text { National Institutes of Health International Research Forum (2008-2 } \\
\text { posters; 2009-2 posters; 2010-1 poster; 2011-1 poster; 2012-2 posters) }\end{array}$} \\
\hline Group 2010-2011 & 10 graduates & \\
\hline Group 2011-2012 & 10 graduates & \\
\hline Group 2012-2013 & 10 in process to graduate & \\
\hline Group 2013-2014 & 10 in process to graduate & \\
\hline Total & 91 participants & \\
\hline
\end{tabular}

\section{Challenges of the program}

Even though there are many indications of success, the program faces several challenges on an ongoing basis. A central concern has been the provision of funding for the program. The Canadian Government has generously provided funding on an annual basis, but longer-term funding commitments (e.g., for five years) would facilitate longer-term planning and permit extension of the program to address new issues.

Other challenges relate to the multinational and multilingual nature of the program. Participants are drawn from Spanish, Portuguese and
English-speaking countries, and communications challenges can arise when dealing with the complex theoretical and methodological considerations involved in carrying out a multinational research project. Participants may have limited experience in conducting research, and in publishing results. This limited experience may be compounded when they return to their home institutions and regular academic workloads, with a commitment to carry out the research plan within an agreed-upon time and with a very limited budget. Ethics and other approvals required at home institutions must also be met and are sometimes 
lengthy. Finally, communications among investigators are necessary at different stages of the projects, typically involving emailing, and this can be slow because of the varying academic demands and schedules of investigators.

\section{Impact of the program}

In spite of the challenges that have been encountered in implementing and carrying out the program, it has achieved remarkable success on several fronts. The program has identified and fostered a group of exceptionally talented and committed faculty from Latin American and the Caribbean, and furthered their engagement in research on the drug phenomenon in the region. Several of these individuals have pursued advanced research and professional training in Latin America and the Caribbean, North America and Europe and have been successful in obtaining very competitive fellowship support for this advanced training. In addition, the program has led to substantial research productivity in terms of presentations at national and international conferences and publications in international journals. ${ }^{12}$ A cadre of active researchers on drug issues and demand reduction has been created in Latin America and the Caribbean. Ongoing linkages and interactions among these researchers are being facilitated by the Latin American Network of Researchers on Drugs and the newly-formed IRCBP Alumni Association. The existence of this cadre of researchers also creates important opportunities for a Pan-American network of drug researchers to facilitate knowledge transfer and effective policy and program interventions, and to develop international programs of research.

Many participants have also taken on academic leadership positions at their home institutions and in national drug commissions. Additionally, graduates have strengthened the drug-related aspects of undergraduate, graduate and professional programs in their home institutions, and have held leadership roles in CICAD-led initiatives to strengthen educational and professional programs across the region.

\section{External evaluation of the program}

In 2012, CICAD/OAS hired an external evaluator to conduct a complete evaluation of the program. The findings from the evaluation indicated that $99 \%$ of the participants have been able to comply with all the requirements of the program (graduation, communication and dissemination of the research findings and publications). It also indicated the International Research Capacity-Building Program (IRCBP) is highly relevant in helping to satisfy an acknowledged need for evidence-based research in Latin America and the Caribbean.

\section{FINAL CONSIDERATIONS}

In a relatively short period of time, the International Research Capacity-Building Program for Health and Related Professionals to Study the Drug Phenomenon in Latin America and the Caribbean has achieved some exceptional successes. The program has built lasting international links among drug researchers in South/Central America, the Caribbean and North America. Several ambitious multinational research projects have contributed substantially to our understanding of drug issues in LAC countries. Thus, the program has achieved and exceeded its goals, and continuation of the program will further serve the important purpose of increasing the research capacity necessary to implement and support effective drug demand reduction programs and policies in Latin America and the Caribbean, and in the Americas more generally.

Nevertheless, important challenges remain. The most critical is the need to obtain stable, multiyear funding to support the program. Additionally, expanding the capability of the program to support new multicentric studies by program alumni would be a very significant advance, and provide an important next step in creating and maintaining the research capacity necessary for effective efforts to address the drug phenomenon in the Americas.

\section{ACKNOWLEDGMENT}

OAS/SMS/CICAD-CAMH would like to express our sincerely thanks to the Government of Canada/Foreign Affairs and International Trade Canada for its continuing financial support to the program; to all Universities and National Drug Commissions authorities, and families of the participants for their collaboration, support and understanding of the importance and value of the program; to all faculty and advisors for their time, collaboration, and support to make this program to exceed its academic and scientific contribution to the study of the drug phenomenon in Latin America and the Caribbean; to all participants of the program to accept the challenges the program 
imposes; to the Coordinators and Administrative personnel of the program for their continued collaboration, dedication, and support to make this program possible and successful, and finally to all population samples who participated in the different multicentric drug studies implemented by the participants of the program.

\section{REFERENCES}

1. United Nations Office on Drugs and Crime. World Drug Report. Vienna: UNODC; 2011.

2. Organization of American States, Secretary for Multidimensional Security, Interamerican Drug Control Abuse Commission. Hemispheric drug strategy. Washington (DC): OAS; 2010.

3. Latin American Commission on Drugs and Democracy. Drugs and democracy: toward a paradigm shift [online]. 2011 [access 2012 Apr 10]. Available at: www.drogasedemocracia.org/ Arquivos/declaração_Ingles_site.pdf

4. Organization of American States, Secretariat for Multidimensional Security, Interamerican Drug Control Abuse Commission. Multilateral evaluation mechanism. hemispheric report. Washington (DC): OAS; 2011.

5. United Nations Office on Drugs and Crime, World Health Organization. Programme on drug dependence treatment and care. 2010 [access 2012 Apr 10]. Available at: www.unodcorg/docs/
treatment/unodc_WHO_programme _ brochure _ English.pdf

6. National Institute of Health, National Institute of Drug Addiction. NIDA International Program. 2011 [access 2012 Apr 10]. Available at: http:/ / grants.nih. gov/guide/pa-files/PA-12-040.html.

7. Wright MGM. A Critical-Holistic Paradigm for an Interdependent World. Am Behav Scient. 2000; 43(5):808-24.

8. Wright MGM. La contribución de la enfermería frente al fenómeno de las drogas y la violencia en América Latina: un proceso en construcción. Ciencia Enferm. 2002; 8(2):9-19.

9. Organization of American States, Interamerican Drug Control Abuse Commission. The Role of nursing profession and the drug phenomenon in Latin America. Washington (DC)/Florianópolis (SC): OAS/Universidade Federal de Santa Catarina; 2006.

10. Organization of American States, Secretary for Multidimensional Security, Interamerican Drug Control Abuse Commission. Hemispheric drug strategy: plan of action 2011-2015.Washington (DC): OAS; 2011.

11. Wright MGM, Caufield C, Gray G, Olson J. International research capacity-building programs for nurses to study the drug phenomenon in Latin America: challenges and perspectives. Rev LatinoAm Enfermagem. 2005; 13(2):1-8.

12. Wright MGM, Cumsille F, Khenti A, Padilha MI. Editorial. Texto Contexto Enferm. 2012 Jan-Mar; 21(Special):11-2. 